\title{
Blogging in the 21st-Century Classroom
}

\author{
Jasminka Kochoska ${ }^{1}$, Josif Petrovski ${ }^{2}$ \\ ${ }^{1}$ University "St.Kliment Ohridski“, Faculty of Education-Bitola, "Vasko Karangelevski“" bb, Bitola, 7000, R.Macedonia \\ ${ }^{2}$ University "St.Kliment Ohridski“, Faculty of Education-Bitola, "Vasko Karangelevski“" bb, Bitola, 7000, R.Macedonia
}

\begin{abstract}
Every classroom needs a moderated, online space where students can share their ideas with others and receive feedback. While blogging has "been around" and used in classrooms all over the world for more than ten years now, classroom blogs are still rare in many schools and communities. Blogging is a fantastic way to strengthen the connections between home, school and the world. Like other kinds of technology, blogging platforms have continued to evolve and change, but the reasons why students should regularly blog have remained consistent. Blogging, as assignment can be adapted to every grade and subject area. Encouraging students to blog about topics from other classes helps them see connections among subjects and realize that writing is a worthwhile skill in any field. Blogs have the potential to expand student creativity and their writing skills. These are 21st century students and are adapting to a digital world that they are eager to learn from. Educators are using blogs in many ways including as online portfolios, for student personal reflective journals, as a record of field notes, as discipline specific spaces for knowledge sharing, as a space for student dialogue and for class administration. These days there are so many social networks, but there's something about having a space, potentially free from the distractions of a billion adverts and countless competing status updates.
\end{abstract}

Keywords: blog, education, students, technology

\section{Introduction}

Educators are encouraged to integrate technology into their classrooms because today the students are exposed to all sorts of digital devices in their daily life. Classroom blogging is an excellent way to use the internet for more than just research. Educational blog can serve as an online portfolio to showcase student work. It can give the "silent student" a voice by allowing them the opportunity to write on topics of interest. Student work is available immediately for peers to review or for others on the World Wide Web to comment and post feedback. All of these factors can be motivating for students to learn. All these factors, related to the blog, can have a motivating effect on student performance and their learning. [11]

Using blogs as a teaching tool appear along with increased student interest in introducing digital literacy skills in the classroom as a means of preparing students for the $21 \mathrm{st}$ century marketplace.

Blogs can be used to improve student writing, especially for developing skill in analysis and critique. Blogs provide a means for student response to or discussion of outside-ofclass readings that are not adequately covered during class. They can be useful as a forum for group projects, or act as a collaborative authoring tool for students to develop and present a group assignment or project. Blogs can be a place where students reflect on readings, much as analog journaling was used as a pedagogical tool in the past. [4]

\section{The Meaning of the Term Educational Blog}

An educational blog is publication mechanism, like a journal or bulletin which is created for educational purposes. Mainly it is made to archive and support student and teacher learning by facilitating reflection, questioning by self and others, collaboration and by providing contexts for engaging in higher-order thinking. Educational blogs can be used to promote open dialogue and encourage community building in which both the bloggers and commenters exchange opinions, ideas, and attitudes. Teachers can use a blog to publish instructional materials that the students can access to and where the students can make comments. Teachers can also let students set up their own blogs for a particular subject or for several subjects and then assign tasks to students.

This is one of the ways for teachers to observe and monitor the students' progress, and identify the learning needs that have not been considered. Teachers can classify, summarize and evaluate different students' blogs and then publish the teachers' opinions, directions, and feedback on their own blogs or on class blogs. Actually by doing this, teachers are putting students to the right tracks, because if you just let students publish whatever they like, the use of blog could be out of control, and the relevance between the blog and the content being taught and learning will be reduced. [14] There are several possible ways of using the power of educational blogging in a classroom context. These are the main ones:

- Teacher communications-using a blog to communicate school or class news with students and their parents.

- Teacher blogging about the subject- to encourage debate among students, to engage them actively with the content by leaving comments with their opinions.

- Student blogging- each student can contribute under their own user profile or each student has their own blog for sharing their thoughts about a particular subject or subjects. [5]

A blog is a frequently updated website consisting of dated entries called posts (including text, images, media objects, and data) arranged in reverse chronological order so the most recent entry appears first. Each post can have three basic attributes: title, link, and description. Educational blog can be used as virtual environments where all students can

\section{Volume 6 Issue 1, January 2017




\section{International Journal of Science and Research (IJSR) \\ ISSN (Online): 2319-7064}

Index Copernicus Value (2015): 78.96 | Impact Factor (2015): 6.391

participate in critical discourse on scientific topics. They can be published by an individual or small group of individuals in a personal and informal style. It also can be a useful tool to link communication between study groups within a class or other classes or even schools. If use effectively, blogs can create a learning environment that extend beyond the schoolyard. [10]

Blogs are native to the web, so they can dynamically take advantage of the interconnected nature of the web. Diaries and journals are native to paper- they can only statically refer to other information sources. Blogs, on the other hand, provide a doorway, through the hyperlink, directly to that idea. Generally, they include space for public comments at the end of each post. Hence, they are motivated by the topic of the thread (general theme of a post) but are nevertheless a form of discussion through ongoing commentary. This progression from post to comments then a new post to more comments in many ways reflects the practice of professionals in the scientific community. The structure of blogging has great potential to support professional methods of practice in science. [6]

\section{The Use of Blogs in Education}

Blogging has transformed teaching and learning by developing a learning network. There is an authentic audience, a global audience- one that is willing to connect, share, challenge, discuss and communicate with others. This audience can provide further information, opinions, suggest resources, seek answers to questions etc. which pushes the blogging further. Students have online space and attempt to keep work accurate and pleasing to the eye. It extends their learning beyond the classrooms and increases their exposure to other teachers across the globe. It gives an insight into the complexity of the students- their likes, dislikes, what they do outside school etc. Students are no longer confined to their class groupings or teachers within a classroom. [9]

Every classroom needs a moderated, online space where students can share their ideas with others and receive feedback. While blogging has "been around" and used in classrooms all over the world for more than ten years now, classroom blogs are still rare in many schools and communities. Like other kinds of technology, blogging platforms have continued to evolve and change, but the reasons why students should regularly blog have remained consistent. [2]

Blogs can serve at least four basic functions.

- Classroom Management- Educational blogs can serve as a portal to foster a community of learners. As they are easy to create and update efficiently, they can be used to inform students of class requirements, post handouts, notices, and homework assignments, or act as a question and answer board.

- Collaboration- Blogs provide a space where teachers and students can work to further develop writing or other skills with the advantage of an instant audience. Teachers can offer instructional tips, while students can practice and benefit from peer review. They also make online mentoring possible. Students can also participate in cooperative learning activities that require them to relay research findings, ideas, or suggestions.

- Discussions- A class blog opens the opportunity for students to discuss topics outside of the classroom. This is the way where every person has an equal opportunity to share their thoughts and opinions. Students have time to be reactive to one another and reflective. Teachers can also bring together a group of knowledgeable individuals for a given unit of study for students to network and conference with on a blog.

- Student Portfolios- Educational blogs can present organize and protect student work as digital portfolios. As older entries are archived, developing skills and progress may be analyzed more conveniently. Additionally, as students realize their efforts will be published, they are typically more motivated to produce better writing. Teachers and peers may conference with a student individually on a developing work, and expert or peer mentoring advice can be easily kept for future reference. [10]

Regarding the use of educational blogs is important to note the following. Students should build their blogging "skill set". They should learn about quality commenting, blogging etiquette, online safety and blogging terminology amongst other things. A sense of classroom community should be developed. [7] It is necessery for teacher to take action of own classroom blogging program to encourage comments, ensure writing standards remain high, monitor that students are growing their skills, or strengthen links with parents. [8] Students, teachers and parents can learn and share together all the wonderful things that are happening in the classroom. A sense of identity for the class is also developed and the blog becomes an online meeting place for all. Parents can also learn about blogging. Educating parents about blogging is very important. Parents won't be willing or able to get involved in your class or student blogs if they don't have the knowledge and skills required. [7]

These days there are so many social networks, but there's something about having a space, potentially free from the distractions of a billion adverts and countless competing status updates. And the best thing is, there are a load of free blogs out there to get started. Considering that blog is a great way to express the thoughts, there is an opportunity to create a web presence to provide content to Internet users.

There are many blog- publishing services, but the most popular are these: Contentful, Jekyll, WordPress, Tumblr, Blogger, Medium, Svbtle, LiveJournal, Weebly, Postach.io, Pen.io, Ghost etc. [3]

\section{Benefits of using blogging as a learning tool}

Blogs have the potential to expand student creativity and their writing skills. These are 21 st century students and are adapting to a digital world that they are eager to learn from. Educators are using blogs in many ways including as online portfolios, for student personal reflective journals, as a record of field notes, as discipline specific spaces for knowledge sharing, as a space for student dialogue and for class administration. To keep up with cutting edge research as it happens. [1] Fortunately for teachers, blogs are 


\section{International Journal of Science and Research (IJSR) \\ ISSN (Online): 2319-7064}

Index Copernicus Value (2015): 78.96 | Impact Factor (2015): 6.391

surprisingly easy to use. They require minimum technical knowledge and are quickly and easily created and maintained. Students will be able to pick up how to use blogging platforms with minimal technical assistance and teachers will enjoy the ease in the initial setup. Students and teachers will find them convenient and accessible via any computer or mobile device. [12]

There are numerous educational benefits of blogs. Blogs are:

- Highly motivating to students, especially for those who might not become participants in classrooms.

- Excellent opportunities for students to read and write.

- Effective forums for collaboration and discussion.

- Powerful tools to enable scaffolding learning or mentoring to occur.

Blogging allows students to express their opinion, to articulate their views and build a readership, which can be a very motivating experience for them. Sharing ideas on the internet can also put them in touch with like-minded individuals and with those who may challenge their ideas, which means that they may be required to defend their opinions.

It's great experience which demonstrates enthusiasm for the subject and a willingness to share ideas with others, as well as developing enthusiasm for communicating ideas in a way that will prove useful beyond the classroom. It also teaches students about the importance of 'responsible journalism' such as backing up ideas with concrete evidence, citing research and so on.

Blogging about a subject is more engaging than simply reading a textbook. If students are to write about a subject on a public platform like a blog, they need to be completely familiar with the subject and comfortable expressing an opinion about it. This encourages a deeper understanding and greater engagement with the subject. Unlike when they write an essay that only the teacher will read, blogging gives their work an indefinite life beyond the classroom and invites others to engage with it. [5]

Blogs are of high benefit to the education system. Blogs:

- Are personalized and customized online spaces and a source of pride.

- Enable a full range of media to be used catering for the diversity of student learning styles.

- Are a necessary 21 st century digital skill and teaches many digital literacy skills

- Can be used to learn in a practical manner the following: cyber safety, netiquette and digital citizenship

- Provide an online space for further interaction, conversations, connection and communication with others from across the globe.

- Become a digital portfolio with all their associated benefits.

- extends learning to anywhere and anytime 24/7, supporting a flipped classroom approach

- Facilitates a network that is global [9]

As an example of the benefits of using blogs we can refer to the following research. A study conducted in 2012, surveyed teachers on the use of educational blogs and benefits of student blogging, among other things, gave the following answers:

- Students expect more of themselves, and the teacher expects more of them too. They no longer create just for the teacher, but they create for the world.

- Students are more reflective about their own learning because of their blogs. They are able to look at their learning, think about the process, and then write about the experience. Additionally, the students love feedback that goes beyond our classroom walls.

- Blogging opened up the possibilities of audience in new ways. So, when they are considering writing or publishing for an audience other than the teacher, that really impacts how they view what they doing and the intrinsic motivation they have.

- Students love seeing their work on the Internet and adore getting comments from people. It motivates them to write as it gives them an audience that is real. They find it hard to be motivated when they know the writing is just going in their books and will only be read by themselves, the teacher and their parents. The blog opens up a whole new world of people who can offer encouragement and feedback.

- The blogging experience has forced the students to do more reflection on their learning and has allowed them to showcase products they have produced with online tools.

- Blogging provides an authentic educational experience, where what they write is not only seen and commented on by their teacher, but by their peers and the "public". For most students, it's a bit of extra motivation knowing their peers will see their work.

- There is an authentic audience- a global audience- one that is willing to connect, share, challenge, discuss and communicate with us. This audience can provide further information, opinions, suggest resources, seek answers to questions etc. which pushes the blogging further.

- Blogging develops a learning network. [13]

Educational blogs provides a wide range of learning abilities and introduces a range of media that give added impact. Students use technology constantly outside school, so blogging is a great opportunity for using technology for learning within and beyond the classroom. Technology allows learning to become accessible from any region and networking is enabled on a global scale. The collective ideas, resources, established or innovative units of teaching/learning, experiences from a combined "global brain"will push the learning and teaching to more powerful levels.

\section{References}

[1] Adele Aubrey, M. J. (2009, December 09). Aligning collaborative learning theory with technology. Retrieved November 15, 2016, from University of Manchester/The Centre for Excellence in EnquiryBased Learning (CEEBL): http://www.ceebl.manchester.ac.uk/events/archive/align ingcollaborativelearning/Blog.pdf

[2] Fryer, W. (2015, August 05). Classroom Blogging Options. Retrieved January 03, 2017, from Speed of 


\section{International Journal of Science and Research (IJSR) \\ ISSN (Online): 2319-7064}

Index Copernicus Value (2015): 78.96 | Impact Factor (2015): 6.391

Creativity:

http://www.speedofcreativity.org/2015/08/05/classroom -blogging-options-august-2015/

[3] Grannell, C. (2016, August 30). The 12 best free blogging platforms. Retrieved November 16, 2016, from Creative Blog/Art and Design Inspiration: http://www.creativebloq.com/web-design/bestblogging-platforms-121413634

[4] Hall, M. (2013, November 27). Using Blogging as a Learning Tool. Retrieved December 16, 2016, from Johns Hopkins University/The Innovative Instructor Blog: $\quad$ http://ii.library.jhu.edu/2013/11/27/usingblogging-as-a-learning-tool/

[5] Karen. (2016, December 15). Start Blogging Online. Retrieved January 03, 2017, from Blogging in classroom - How to get started: https://startbloggingonline.com/get-started-classroomblogging/

[6] Klein, E. B. (2006, April 25). Blogs. Retrieved October 12, 2016, from National Science Teachers AssociationNSTA WebNews Digest: http://www.nsta.org/publications/news/story.aspx?id=51 966

[7] Morris, M. K. (2013, April 25). Student Blogs: Digital Portfolios. Retrieved January 03, 2017, from Primary Tech:

http://primarytech.global2.vic.edu.au/2013/04/25/studen t-blogs-digital-portfolios/

[8] Morris, M. K. (2013, May 17). There's Blogging and There's Blogging.... Retrieved January 03, 2017, from Primary Tech: http://primarytech.global2.vic.edu.au/2013/05/17/theres -blogging-and-theres-blogging/

[9] murcha. (2012, June 10). The Phenomenon that is Blogging. Retrieved October 15, 2016, from On an eJourney with Generation Y: https://murcha.wordpress.com/2012/06/10/thephenomenon-that-is-blogging/

[10] Nguyen, T. (2006, November 14). The use of blogs in education. Retrieved November 24, 2016, from Blogs in Education:

http://thanhnguyen75.blogspot.mk/2006/11/use-ofblogs-in-education_14.html

[11] Sawmiller, A. (2010). Classroom Blogging: What Is the Role in Science Learning? Retrieved December 26, 2016, from ERIC: https://eric.ed.gov/?id=EJ872043

[12] Shekhter, H. (2015, May 30). Why Teachers and Students Should Blog. Retrieved November 18, 2016, from Edudemic/Connecting Education\&Technology: http://www.edudemic.com/how-and-why-teachersshould-blog/

[13] Waters, S. (2012, July 26). The State of Educational Blogging in 2012. Retrieved November 18, 2016, from Edublogs:

http://www.theedublogger.com/2012/07/26/the-state-ofeducational-blogging-in-2012/\#used

[14] Work, T. U.-F. (2016, June 03). Blogs for education. Retrieved December 25, 2016, from The University of Sydney-Faculty of Education and Social Work/Teaching with ICT: http://sydney.edu.au/education_social_work/learning_te aching/ict/theory/internet/blogs.shtml

\section{Author Profile}

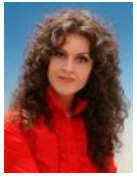

Jasminka Kochoska is an assistant professor at the Faculty of Education at University "St. Kliment Ohridski" in Bitola, R.Macedonia. She teaches methodics, but the main subject is Civic and Multicultural Education with Methodics. She performs lectures and exercises with a group of future teachers and educators for kindergarten. Her interest is in the field of democratization of the educational process and all segments of Civic and Multicultural Education. Each year takes active part in organizing and carrying out the pedagogical practice with students, as one of the most important segment. She has participated in several research projects, scientific workshops in the field of pedagogical sciences and ICT technology. At this period she gave a large number of training sessions for Civic and Multicultural Education. Prof. Kochoska earned her doctorate in Pedagogy in the field of methodics at Faculty of Education at University "St. Kliment Ohridski“" in Bitola, R.Macedonia.

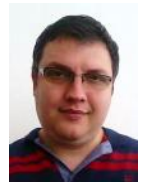

Josif Petrovski is an ICT administrator at the Faculty of Education at University "St. Kliment Ohridski" in Bitola, R.Macedonia. He also performs lectures and exercises with a group of students from the study program "Informatics and Technical Education". He has attended many conferences and scientific projects and workshops in the field of ICT. During his employment at the Faculty of Education, Josif held a lot of training sessions for people who want to learn computer sciences. He has a master degree in Computer Sciences and at this moment is finishing his $\mathrm{PhD}$ studies in the field of computer programming. 